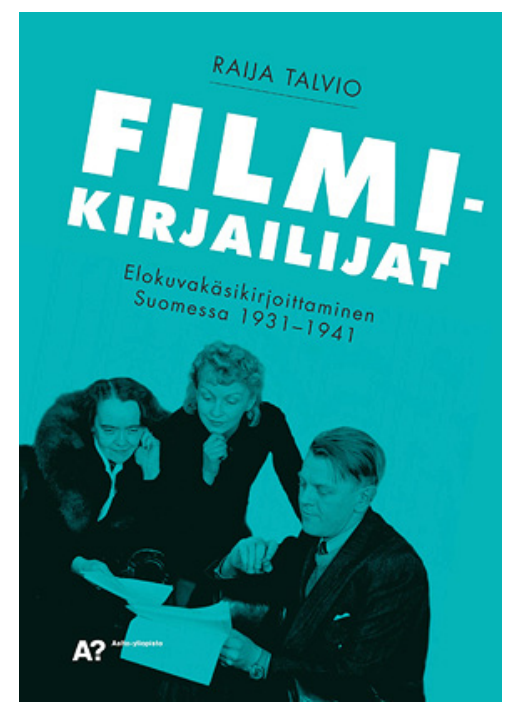

Raija Talvion väitöskirja Filmikirjailijat. Elokuvakäsikirjoittaminen Suomessa 1931-1941 on vankkaa tekoa: kaikkine osineen 326 sivua käsittävä teos. Koostaan huolimatta se istuu hyvin lukijan käteen, ja sen ulkonäkö on puhutteleva niin ajatuksella valittujen väriensä kuin kuvituksensakin puolesta. Teoksen graafinen suunnittelija Emmi Kyytsönen ei kuulu väitöskirjassa kiitettävien joukkoon. Annettakoon siis tässä yhteydessä kiitos myös hänelle työpanoksesta.

Filmikirjailijat sisältää kolme osaa: alun, keskikohdan ja lopun. Alun voidaan katsoa jakautuvan niin ikään kolmeen osaan: jo mainitut kiitokset, teoksen johdanto ja tutkimuksen kohteen paikantaminen rajattuun aikakauteen - vuosien 1931 ja 1941 välille - ja siihen liittyvän aate- tai ajatusmaailmaan esittely. Ennen kaikkea väitöskirjan alussa valotetaan Suomessa vallitsevaa ajatusta Suomen kansallisuuden ainutlaatuisuudesta ja elokuvasta yhtenä sen keskeisenä ilmentäjänä, säilyttäjänä ja kehittäjänä.

Väitöskirjan keskikohta jakaantuu neljään osaan. Ensimmäinen osa kertoo keskustelusta suomalaiselle elokuvalle soveliaista aihepiireistä. Toinen osa taas esittelee aikakauden käsityksiä elokuvakäsikirjoittajan ihanteellisesta habituksesta ja sisältää Talvion selvityksen ammattikunnan edustajien todellisesta kompetenssista kyseisenä aikana. Kolmas osa purkaa keskustelua elokuvakäsikirjoituksen soveliaasta alkuperästä. Näkemyksiä tässä asiassa oli lähinnä kaksi: sellaiset, joiden mukaan elokuvan aihepiiri ja perusaines löytyisi parhaiten jo olemassa olevan (näytelmä)kirjallisuuden piiristä, ja sellaiset, jotka esittivät, että elokuva taiteena hyötyisi parhaiten alkuperäiskäsikirjoituksista. Viimeinen osa teoksen keskikohdassa on selonteko keskustelusta, jonka tarkoituksena oli muotoilla hyvän elokuvakäsikirjoituksen pääasialliset ominaisuudet. Kaikki neljä osaa päättyvät yksittäisen casen esittelyyn - eräänlaiseen tapaustutkimukseen, jonka tarkoituksena on syventää, värittää ja/ tai toimia esimerkkinä kyseisen osion ajatuspiiristä.

Väitöskirjan lopun voi katsoa jakautuvan neljään pieneen mutta tärkeään osaan. Näistä ensimmäiseen sisältyy yhteenveto, tiivistelmä ja tiivistelmän englanninkielinen käännös. Toisen osan muodostavat liitteet, joista ehkä tärkein on luettelo kaikista suomalaisten elokuvien käsikirjoittajista, jotka toimivat vuosina 1931-1941. Kolmannen osan taas muodostavat lähdeluettelot ja neljännen hakemistot.

Syynä tekemääni jaotteluun on osoittaa, että väitöskirjassa siellä täällä vilahtavan Aristoteleen Runousopin esittämää draaman kolmijakoisuutta voi soveltaa oikeastaan mihin tahansa. Jos sitä käytetään (draaman, elokuvan tai miksei käsikirjoituksienkin) analyysin välineenä, olisi syytä kuitenkin ottaa mukaan Runousopin koko käsitearsenaali, jotta soveltamisesta olisi hyötyä. Tämä ei kuitenkaan ole ollut Talvion varsinaisena tarkoituksena, vaan niin Aristoteles kuin Pierre Bourdieukin otetaan esille vain silloin, kun työ tuntuu vaativan jonkinlaista teoreettista raamia - ja tällöinkin heidän ajatuksiaan esitellään vain 
päällisin puolin. Bourdieulta on kuitenkin lähtöisin Talvion käyttämä käsite doksa, joka pitää sisällään ne ammatilliset tiedot ja osaamiset, jotka olivat (ja ovat) käsikirjoitusten parissa työskentelevien pääomaa.

Teoria, siihen yhdistäminen ja havaittujen asiantilojen selittäminen (explikaatio) ei siis ole tämän tutkimustyön keskeisin eikä vankin piirre. Sen peruskysymys koskee arvoja ja niiden esille tuomista. Talvio kysyy (s. 38): "Minkälaiset esteettiset ja ideologiset arvot vaikuttivat elokuvakäsikirjoittamiseen ja käsikirjoittajien ammattikunnan muotoutumiseen?" Koska kysymystä esitettäessä ei kuitenkaan selvitetä, mitä arvolla tässä tarkoitetaan, on vaikeata muodostaa käsitystä siitä, kuinka hyvin kysymykseen lopulta vastataan.

Tietty terminologinen epätarkkuus seuraa muutenkin väitöskirjaa. Ennen pitkää lukija todella haluaisi tietää, mitä esimerkiksi sana scenaristi/skenaristi pitää sisällään tutkijan omana terminä. Vastaus löytynee teoksen loppupuolelta, jossa mainitaan, että merkkinä käsikirjoittajan ammatin muotoutumattomuudesta on muun muassa ollut ammattinimikkeiden epämääräisyys, mistä annetaankin useita esimerkkejä (s. 246). Olisi kuitenkin ollut toivottavaa tehdä selvä ero sen välillä, mitä ilmaisuja lähteistä on löytynyt ja miten ne on aikanaan ymmärretty, ja toisaalta sen, miten tutkija itse määrittelee työnsä terminologiaan kuuluvat ilmaisut. Nyt tutkijan kielenkäytössä esimerkiksi sana skenaristi näyttää paikka paikoin synonyymilta ilmaisulle käsikirjoituksen tekijä, samalla kun näiden kahden tittelin välille yritetään tutkimusta tehdessä löytää ero.

Tästä kaikesta huolimatta on todettava, että jos Talvion väitöskirjaa luonnehtii induktiivisen tutkimuksen tulokseksi ja esimerkiksi perustutkimuksesta, on se kiinnostava, hyvin ja oivaltaen kirjoitettu ja ajatuksia herättävä opinnäytetyö. Tutkimuskohteen rajaus on perusteltua, ja työ kartoittaa systemaattisella tavalla suomalaisen elokuvahistorian tärkeätä aikakautta uudesta ja omintakeisesta näkökulmasta. Lähteiden tutkimus on perusteellista. Lähteinä ovat ensisijaisesti olleet aikakaus- ja muut lehdet sekä erilaiset painotuotteet, joissa elokuvien tekijät esittelevät elokuviaan tuotannon alkuvaiheissa ja ensi-iltojen alla.

Talvio huomauttaa jo johdannossa, että käsikirjoittamista määritelleen ja muokanneen julkisen mediakeskustelun valinta ensisijaiseksi lähdeaineistoksi ei ole ollut ongelmatonta (s. 46). Tämä pitää paikkansa, sillä lehtien ja esitteiden sisältämä tieto ja keskustelu pystyvät antamaan kuvan periaatteessa vain siitä, miten asioiden on oletettu olevan ja miten niiden on toivottu olevan - mutta ei välttämättä siitä, miten ne todella ovat olleet.

Tällaisessa tutkimuksessa on aina tavalla tai toisella kysymys valintaperiaatteista ja siitä, edustavatko valitut suureet todella kokonaisuutta. Talvion luotettavana ratkaisuna tähän ongelmaan on ollut käyttää runsasta sitaatti- ja viiteapparaattia (lähdeviitteiden määrän noustessa yli kahdeksansadan). Hän siis tukee ja valottaa johtopäätöksiään monilla esimerkeillä. Sitaatit antavat autenttisuuden tuntua tarjoten lukijalle myös tietyn vapauden omien käsitystensä luomiseen. Parhaillaan sitaattien runsas käyttö antaa lukijalle mahdollisuuden ikään kuin ottaa osaa tutkimuksen ytimeen.

Täten Talvio on tehnyt erinomaista työtä tarjoten monipuolisen kuvan vuosikymmenen aikana jatkuneesta keskustelusta ja niistä muutoksista, jotka tapahtuivat elokuvatuotannon vakiintumisen myötä. Vakiintuminen saattoi johtua kyseisestä keskustelusta tai tapahtua siitä huolimatta. Esimerkkinä vakiintumisesta on pieneltä vaikuttava mutta lisääntyvää ammatillisuutta luonnehtiva väline, nimittäin käsikirjoitusta varten suunniteltu työpaperi. Ensimmäisiä työpapereita on löytynyt jo vuodelta 1933, ja ilmeisestikin ne vakiintuivat käyttöön vuosikymmenen puoliväliin mennessä muuntuen yksipalstaisesta kertomuksesta nelipalstaiseksi kaavioksi (s. 252).

Tämän lisäksi käsitellyn vuosikymmenen aikana vakiinnutettiin jo käytössä ollut työjärjestys. Työjärjestyksen mukaan aloite uuteen elokuvaan on usein tullut tuottajataholta ehdotetun aiheen muodossa. Käsikirjoittajan ensimmäinen työtehtävä käsitti synopsiksen tai filminovellin teon, jonka jälkeen oli vuorossa skenarion - jota voitiin myös nimittää kuvauskäsikirjoitukseksi - suunnittelu. Viimeksi mainittuja saattoi olla useita ja, kuten sanottu, se, mikä näiden tekemiseen osallistuneiden henkilöiden ammattinimike kulloinkin on ollut, ei tainnut aina olla selvää edes heille itselleen.

Mainittakoon vielä, että usein käsikirjoitusprosessiin liittyi useita henkilöitä mahdollisen alkuperäisromaanin tai näytelmän kirjoittajas- 
ta siinä esiintyvään näyttelijään asti - ohjaajasta puhumattakaan. Siksi teoksen loppuun liitteenä lisätty elokuvakäsikirjoittajien luettelo on kiinnostavaa luettavaa. Se sisältää 85 henkilönimeä. Jokaisen nimen kohdalla on mainittu henkilön mahdollisesti käyttämät nimimerkit, muut ammatit sekä niiden elokuvien nimet, joiden luomiseen kyseinen henkilö on osallistunut. Neljätoista listatuista ammattilaisista on naisia.

Mielenkiintoisia ovat myös Talvion löydökset elokuvakäsikirjoittajien taustasta ja koulutuksesta, jota ei muodollisesti ollut olemassakaan. Tätä ammattikuntaa moitittiin joskus puolioppineeksi, mutta Talvio toteaa asiaa tutkittuaan: "Suomalaiset elokuvakäsikirjoittajat olivat koulutettu, kielitaitoinen ja kansainvälisesti orientoitunut joukko", jossa virkamieseliitin ja ylemmän keskiluokan taustasta tulevat olivat yliedustettuina (s. 150).

Kansainvälisestä orientoitumisestaan huolimatta valjastautuivat elokuvakäsikirjoittajat käsiteltynä vuosikymmenenä mitä suurimmassa määrin isänmaalisuuden ja kansallisen kulttuurin luomisen ja ylläpitämisen tehtävään. Myös väitöskirjan tekijä Raija Talvio allekirjoittaa kyselemättä yleisen suomalaisen elokuvatutkimuksen käsityksen, jonka mukaan kotimainen elokuva on monipuolisesti kansallinen tuote. Tätä olisikin vaikea kiistää, niin yksiselitteistä on esimerkiksi elokuvien tuottajien retoriikka (aina) ollut. Käsitystä tukee myös tutkijan huomio, jonka mukaan maan ruotsalaisen vähemmistön oli luovuttava kielestään, jos mieli käsikirjoittaa elokuvia. Samalla Talvio kuitenkin osoittaa kansallisuusparadigman mahdollisia rakoja keskustellessaan ulkomaalaisten vaikutusten runsaudesta 1930-luvulla. Hän muistuttaa myös monien elokuvatyöntekijöiden maahanmuuttajataustasta. Ehkäpä näistä havainnoista avautuu uusi tutkimuksen ura: mitä muuta kansallinen elokuva on (ollut) kuin yhteen hiileen puhaltamista?

\section{Tytti Soila}

FT, Filmvetenskap, Tukholman yliopisto 